\author{
Agnieszka Świętek \\ Wiktor Osuch \\ Tomasz Rachwal \\ Slawomir Kurek \\ Uniwersytet Pedagogiczny \\ im. Komisji Edukacji Narodowej \\ w Krakowie
}

\title{
Projekt „Common Goals - Common Ways” jako przyklad aktywizacji grupy Romów zagrożonych wykluczeniem społecznym i ekonomicznym
}

\author{
The project "Common Goals - Common Ways" as an example of activation \\ of Roma group at risk of social and economic exclusion
}

\begin{abstract}
Streszczenie
W związku z coraz słabszym zainteresowaniem instytucji edukacyjnych tak potrzebnym współcześnie kształceniem zawodowym oraz nawiązywaniem i utrzymywaniem przez szkoły zawodowe kontaktu z podmiotami rynku pracy, jak również potrzebą świadomego planowania kariery zawodowej uczniów, podjęto badania dotyczące aktywizacji grup najbardziej zagrożonych wykluczeniem społecznym i ekonomicznym - Romów. Badania realizowano w latach 2012-2014 w trzech krajach: w Niemczech (głównie przykłady z Bawarii), w Szkocji oraz w Polsce. Dotyczyły one szkolnictwa zawodowego oraz możliwości transferu innowacji w kontekście docelowej aktywizacji mniejszości romskiej na Węgrzech. W tym celu wykorzystano prace badawcze prowadzone w ramach międzynarodowego projektu „Common Goals - Common Ways”, pokazując rolę i zadania poszczególnych partnerów zagranicznych w przygotowaniu, testowaniu oraz wdrażaniu programu kształcenia Romów w kontekście ich przyszłej aktywizacji zawodowej. Pomimo różnych uwarunkowań kulturowych, społecznych, ekonomicznych oraz integracyjnych edukacja młodych Romów, a zwłaszcza usuwanie wszelkich barier edukacyjnych, stanowi najważniejszy aspekt przyszłej aktywizacji zawodowej, rozwoju motywacji i kształtowania postaw przedsiębiorczych mniejszości romskiej w wielu krajach Unii Europejskiej, w tym na Węgrzech i w Polsce.
\end{abstract}

\begin{abstract}
Due to the declining interest of educational institutions in vocational training much needed today, and in establishing and maintaining contact between vocational schools and labour market entities, as well as the needs of conscious career planning by students, research was undertaken for the activation of those groups at high risk of social and economic exclusion, including the Roma population. This study was undertaken in the years 2012-2014 in three countries: Germany (chiefly examples from Bavaria), Scotland and Poland in the field of vocational education and the possibility of transferring innovation within the context of the target activation of the Roma minority in Hungary. In this regard, research work carried out within the framework of the international project titled "Common Goals - Common Ways" was used, showing the role and responsibilities of each of the foreign partners in the preparation, testing, and implementation of the program of educating the Roma population in the context of their future professional activation. In spite of the different
\end{abstract}


cultural, social, economic, and integration backgrounds of the young Roma people, education, and especially the removal of all educational barriers, is the most important aspect of the future of professional activation, as well as developing motivation and shaping entrepreneurial attitudes of the Roma minority in many EU countries, including Hungary and Poland.

Słowa kluczowe: edukacja mniejszości romskiej; szkolnictwo węgierskie; transfer innowacji Keywords: education of the Roma minority; Hungarian education system; transfer

\section{Wstęp}

Współczesne dynamiczne przemiany społeczno-gospodarcze stawiają coraz większe wyzwania edukacyjne przed systemem oświaty w zakresie przygotowania młodych ludzi do życia zawodowego i wejścia na rynek pracy. Szczególną rolę odgrywa tu kształtowanie postaw przedsiębiorczych młodzieży w toku edukacji szkolnej na różnych etapach kształcenia i osób dorosłych w ramach procesu uczenia się przez całe życie (Najda, Wach, 2008), wpływające na możliwości aktywnego uczestnictwa w życiu społeczno-gospodarczym, w tym wejścia na rynek pracy i samozatrudnienia (Daszkiewicz, 2014; Kurek, Rachwał, 2009; Piróg, 2014, 2015; Rachwał, 2010; Wach, 2013, 2014). W związku z tym szerokie jest zainteresowanie ośrodków naukowo-badawczych oraz instytucji oświaty problematyką edukacji w zakresie przedsiębiorczości, w tym aktywizacji zawodowej młodzieży, czego przykładem jest realizacja wielu projektów badawczych i wdrożeniowych z tego zakresu (np. Dorocki et al. 2011; Kurek et al. 2012; Rantanen et al., 2015; Wach, 2015). Szczególne miejsce w tym zakresie obejmują badania wpływu różnych czynników (społecznych, psychologicznych i innych) na zainteresowanie podejmowaniem działalności gospodarczej (Benhabib et al., 2014; Jimenez, Wach, 2014; Kilar, Rachwał, 2014; Kosała 2014; Rantanen et al., 2015; Kulig-Moskwa, Strzelczyk, 2014; Kwieciński, Młodzińska-Granek, 2014; Rokhman, Ahamed, 2015; Safin, 2014; Wach, 2015; Zbierowski, 2014). Z drugiej strony, w ostatnich latach obserwuje się zmniejszające się zainteresowanie instytucji systemu oświaty tak potrzebnym obecnie kształceniem zawodowym, co wynika zarówno z intensywnej promocji wykształcenia ogólnego i akademickiego, jak i z obniżenia rangi wykształcenia zawodowego w świadomości społecznej. W efekcie w wielu krajach obserwuje się coraz słabsze zainteresowanie szkołami zawodowymi oraz, w konsekwencji, braki w dostępie do dobrze wykwalifikowanych fachowców reprezentujących różne zawody. Jednocześnie zauważa się trudności w nawiązywaniu i utrzymywaniu przez szkoły zawodowe kontaktu z podmiotami rynku pracy, jak również potrzebę kształtowania przez szkoły umiejętności świadomego planowania kariery zawodowej uczniów. Jest to szczególnie istotne w przypadku jednej z grup najbardziej zagrożonych wykluczeniem społecznym i ekonomicznym - Romów. W nawiązaniu do tych przesłanek w latach 2012-2014 podjęto prace badawcze w ramach międzynarodowego projektu "Common Goals - Common Ways” w trzech krajach: Niemczech (głównie na przykładach rozwiązań edukacyjnych z Bawarii), Szkocji oraz Polsce. Swoim zakresem objęły one rozpoznanie dobrych praktyk w systemie szkolnictwa zawodowego oraz możliwości transferu innowacji w kontekście docelowej aktywizacji mniejszości romskiej na Węgrzech.

Przedmiotem niniejszego artykułu jest projekt „Common Goals - Common Ways” jako przykład międzynarodowego działania na rzecz aktywizacji grupy Romów zagrożonych wykluczeniem społecznym i ekonomicznym. Celem tekstu jest odpowiedź na trzy pytania badawcze: 
1. Jakie problemy społeczno-ekonomiczne spotyka większość Romów na Węgrzech?,

2. Jak projekt „Common Goals - Common Ways” odpowiada na potrzeby w zakresie poprawy sytuacji społecznej i ekonomicznej mniejszości romskiej na Węgrzech?,

3. Jakie rozwiązania edukacyjne transferowane są z innych krajów i wdrażane na Węgrzech w ramach projektu?.

Dla kompletności opracowania ważniejsze wnioski z realizacji projektu, przykłady dobrych praktyk i rekomendacje dla węgierskiego systemu oświaty przedstawiono na tle analizy rozmieszczenia i sytuacji społeczno-ekonomicznej romskiej mniejszości etnicznej w Europie.

Podjęta przez autorów tematyka sytuacji społeczno-ekonomicznej Romów w innych krajach europejskich, rzadko będąca przedmiotem rozważań polskich badaczy, jest szeroko dyskutowana w literaturze zagranicznej. Wyjątkiem pod tym względem jest artykuł Wójcik (2011), na którego wyniki badań autorzy wielokrotnie się powołują. Wielu danych dotyczących sytuacji społeczno-ekonomicznej Romów w Europie, na podstawie wyników badań empirycznych, dostarczają natomiast raporty instytucji unijnych, z których najważniejsze to: Quality of life in ethnically diverse neighbourhoods (2011) i Living conditions of the Roma: Substandard housing and health (2012). Wielu cennych informacji dostarcza również raport Unijne ramy dotyczace krajowych strategii integracji Romów do 2020 r. (2011).

Dość obszerna jest natomiast polska literatura dotycząca edukacji romskich uczniów w Polsce. Jej analiza oraz badania własne autorów pozwoliły na zaproponowanie w ramach przedstawianego projektu skutecznych rozwiązań możliwych do przeniesienia na grunt węgierski i mogących usprawnić tamtejszy system edukacji romskich uczniów. Bardzo uboga jest natomiast liczba publikacji polskich, których przedmiotem jest sytuacja edukacyjna uczniów romskich w innych krajach. W tym przypadku autorzy korzystali z literatury zagranicznej. W ramach unijnego projektu „CENTIME - From the Margin to the Centre”, koordynowanego przez austriackich geografów, przedstawiono szereg praktycznych rozwiązań w zakresie edukacji grup mniejszości w Europie, w tym w szczególności wśród Romów. Fridrich (2006) opracował teoretyczne założenia identyfikacji grup mniejszości w aspekcie regionalnym. Aktualną sytuację mniejszości romskiej w austriackim Oberwart przedstawiła Probst-Thayanandasivam (2006), uwzględniając wpływ uwarunkowań historycznych na rozmieszczenie tej grupy, jak również efekt zamachu terrorystycznego na Romów w 1995 r. oraz późniejsze, bardzo pozytywne relacje z mieszkańcami miasta. O trudnej sytuacji Romów w Rumunii pisali Poruncia i Nichersu (2006), podkreślając wyjątkowo niekorzystne warunki materialne tej grupy - zwłaszcza mieszkaniowe i ubogie wyżywienie - co nie sprzyjało efektywności edukacji w szkole. Istotnym problemem jest niewystarczające zaangażowanie władz lokalnych w pomoc, jak również wsparcie rodziców romskich, niedostrzegających długotrwałych korzyści w edukacji swoich dzieci.

Zupełnie odmienna sytuacja materialna charakteryzuje Romów w Finlandii (Grönfors, Trotta-Tuomi, 2006). Mogą oni liczyć na pomoc zarówno władz lokalnych, władz oświatowych, jak i wsparcie ze strony samych Romów.

Jednym z niewielu dostępnych opracowań anglojęzycznych na temat prób usprawniania edukacji romskich uczniów na Węgrzech jest publikacja A Successful School Integration Program (Kézdi, Surányi, 2009). Program ten - w przeciwności do projektu „Common Goals Common Ways” - nie zawiera jednak propozycji wdrożenia na Węgrzech rozwiązań skutecznie stosowanych w innych krajach europejskich. W niniejszym artykule autorzy postanowili więc zaprezentować projekt będący odpowiedzią na to zapotrzebowanie. 


\section{Romska mniejszość etniczna w Europie}

Romska mniejszość etniczna jest największą mniejszością w Europie - liczy szacunkowo ok. 10-12 mln osób (Nowicka, 2007). Według szczegółowych informacji Komitetu Ekspertów Rady Europy ds. Romów i Osób Wędrujących, w 2009 r. najwięcej Romów mieszkało w południowej i wschodniej Europie. Zdecydowanie największa ich liczba przebywała na terenie Rumuni - 1,85 mln, Bułgarii - 0,75 mln oraz Węgier - 0,7 mln, a także Serbii (z wyłączeniem Kosowa) - 0,6 mln i Słowacji - 0,5 mln (ryc. 1). Ponadto liczne społeczności romskie występowały również w państwach na pograniczu Europy i Azji: w Turcji - 2,75 mln i Rosji - 0,825 mln. Prócz wskazanych, obecnie Romowie zamieszkują także licznie zaludnione kraje Europy Zachodniej. Powyżej 100 tys. Romów mieszkało w Hiszpanii (0,725 mln), Francji (0,4 mln), Wielkiej Brytanii $(0,225 \mathrm{mln})$, Włoszech $(0,14 \mathrm{mln})$ oraz w Niemczech $(0,105 \mathrm{mln})$ (Unijne ramy dotyczace..., 2011).

Ryc. 1. Liczba i rozmieszczenie Romów w Europie

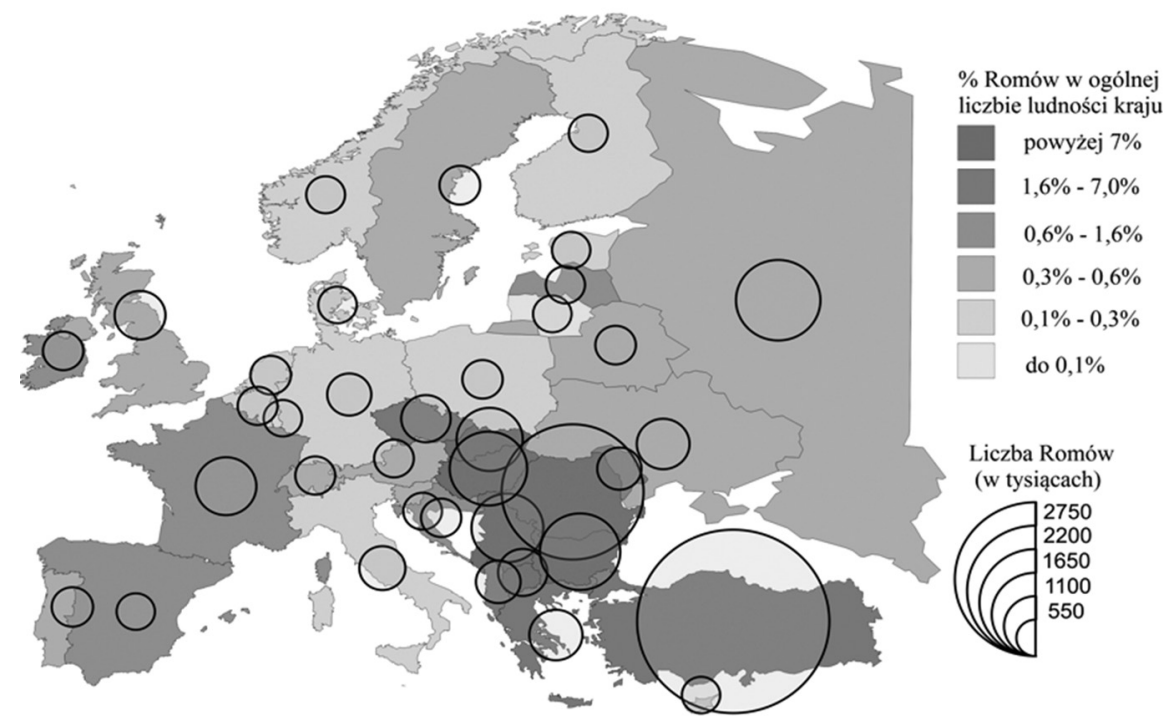

Źródło: opracowanie A. Świętek na podstawie danych Rady Europy i Eurostat.

\section{Sytuacja społeczna Romów w Europie - przykłady konfliktów z mieszkańcami}

Historia mniejszości romskiej w Europie pokazuje liczne przykłady trudnych relacji Romów z ludnością krajów europejskich. Także w ostatnich latach można zaobserwować narastające przykłady konfliktów między migrującymi Romami a mieszkańcami poszczególnych krajów europejskich, wyraźnie przeciwnych ich osiedlaniu się na terenie ich państw. Przyczyną owych konfliktów stało się poniekąd ostatnie rozszerzenie Unii Europejskiej w 2007 r. i otwarcie granic dla państw licznie zamieszkałych przez Romów: Bułgarii i Rumunii, ponieważ zaraz po wstąpieniu do struktur unijnych tych dwóch krajów wiele biednych romskich rodzin wyruszyło na zachód w poszukiwaniu szansy na lepsze życie. W pierwszej kolejności dotarli oni do Włoch. W okolicach dużych miast włoskich założyli nielegalne obozowiska, które z kolei stały się przyczyną niechęci i krytyki rodzimych mieszkańców, a czasem nawet bardziej desperackich kroków, jak np. prób podpaleń w celu pozbycia się niechcianych przybyszy. Z tego 
właśnie powodu, aby uniknąć narastających niepokojów społecznych i coraz częstszych, niebezpiecznych sytuacji, Roberto Maroni - ówczesny minister spraw wewnętrznych Włoch ogłosił w trzech regionach: Kampanii, Lombardii i Lazio, wprowadzenie stanu wyjątkowego (Mirga, 2010).

Nieco inne przyczyny stały się źródłem nowych konfliktów na Węgrzech. W latach 20082009 doszło tam do ok. 30 ataków na Romów z użyciem broni, w wyniku których śmierć poniosło sześć osób. We Włoszech Romowie byli głównie krytykowani za zaśmiecanie miast, żebractwo i wyłudzanie pomocy socjalnej, natomiast przyczyny niechęci na Węgrzech zaczynają być uzasadniane bardzo niebezpieczną ideologią, noszącą znamiona faszyzmu. W ostatnich latach skrajnie nacjonalistyczna partia Jobbik zdobyła znaczne poparcie wyborców i dostała się do węgierskiego parlamentu, otwarcie głosząc antycygańskie poglądy. Dotychczas jej celem było organizowanie marszów nienawiści w miastach węgierskich, licznie zamieszkałych przez Romów (Mirga, 2010).

Według Mirgi (2010), w niektórych zamożnych krajach europejskich, dotkniętych kryzysem gospodarczym, populistyczni politycy wykorzystują podatny grunt, podsuwając sfrustrowanym mieszkańcom za kozła ofiarnego imigrantów, a na ich dyskryminacji budują swój kapitał polityczny. Dowodem na tę tezę może być fakt, że w ostatnich latach w Holandii i Szwecji skrajnie nacjonalistyczne partie, głoszące antyromskie hasła, zyskują duże poparcie społeczne, a we Francji i Włoszech nawet $80 \%$ obywateli popiera antyromskie działania władz państwowych (Mirga, 2010). Spośród niedawnych wydarzeń warto przytoczyć przykłady ze Słowacji i z Francji. Jak donosiła w 2013 r. Polska Agencja Prasowa, w Koszycach, na osiedlu Lunik IX, na którym może mieszkać wg szacunków nawet 8 tys. Romów, miejscowa ludność postawiła kolejny - czternasty już na terenie Słowacji - mur, aby oddzielić się od romskich sąsiadów. Także w sąsiednich Czechach znane są częste przypadki lokalnych konfliktów mieszkańców z Romami. Również w 2013 r. rząd francuski z pomocą francuskich policjantów przeprowadził w Marsylii wysiedlenia 200 nielegalnie obozujących Romów oraz zapowiedział dalszą likwidację nielegalnych obozowisk Romów, a także odsyłanie ich do krajów, skąd pochodzą - głównie Rumunii i Bułgarii.

\section{Sytuacja społeczna i ekonomiczna Romów na Węgrzech - problemy aktywizacji zawodowej}

W powszechnym spisie ludności na Węgrzech, przeprowadzonym w 1990 r., narodowość romską zadeklarowało 143 tys. osób, a w roku 2001 liczba ta wzrosła do 190 tys. Organizacje działające na rzecz ochrony praw ludności romskiej dysponują jednak danymi, które szacują liczbę Romów na Węgrzech na ok. 400 tysięcy do 1 miliona obywateli węgierskich, czyli nawet ok. 10\% populacji kraju (Wójcik, 2011). Najliczniejszą grupę Romów na obszarze współczesnych Węgier, bo aż 2/3, stanowią tzw. Cyganie węgierscy (magyar cigányok). Językiem ojczystym zdecydowanej większości Romów na Węgrzech jest język węgierski (aż 87\%). Tylko ok. $8 \%$ posługuje się oficjalnie językiem romskim, zaś językiem beás (dialekt języka rumuńskiego) ok. 5\%. Języki te, zgodnie z węgierskim prawem, podlegają ochronie prawnej jako języki mniejszościowe (Kemény, Janky, Lengyel, 2004).

Rozmieszczenie ludności romskiej na obszarze Węgier nie jest jednolite, a istotny wpływ na migrację romskiej ludności miała polityka państwa węgierskiego prowadzona po II wojnie światowej. Polegała ona na likwidacji koczowisk romskich oraz zmuszaniu Romów do przenoszenia się na wieś i do małych miejscowości. Wskutek dynamicznego rozwoju przemysłu i dużego zapotrzebowania na siłę roboczą nastąpiły również migracje Romów do miast - podobnie jak w innych krajach socjalistycznych w tym czasie - zwłaszcza do Budapesztu. Upadek systemu socjalistycznego, zapewniającego obywatelom pracę i mieszkania, oraz wpro- 
wadzenie gospodarki rynkowej po 1989 r. przyczyniły się do pogorszenia sytuacji materialnej Romów. Nastąpił wzrost bezrobocia oraz poziomu ubóstwa wśród przedstawicieli tej grupy społecznej - dotychczas wykonywali oni bowiem proste prace w zakładach przemysłowych, niewymagające wykształcenia. Po 1989 r. w pierwszej kolejności stali się ofiarami procesów restrukturyzacji i prywatyzacji. Główną przyczyną był, utrzymujący się do dziś, niski poziom wykształcenia Romów, który z kolei generuje bardzo wysoką stopę bezrobocia. Aż $82 \%$ młodych węgierskich Romów ma zaledwie wykształcenie podstawowe, a tylko 1,2\% - wyższe. Szacuje się, że po 1989 r. bezrobocie w tej grupie społecznej wynosiło 74\% wśród mężczyzn i aż 83\% wśród kobiet, choć aktualnie w samym Budapeszcie sytuacja ta jest nieco lepsza. Bardzo podobnie przedstawia się sytuacja Romów w Polsce.

Z racji braku miejsc pracy dla Romów w miastach, obecnie na Węgrzech obserwowany jest powolny wzrost ich migracji na obszary wiejskie (Wójcik, 2011) - czego dla odmiany w Polsce nie stwierdzono. Aktualnie aż 60\% ludności romskiej zamieszkuje obszary wiejskie, zwłaszcza północno-wschodnią część Węgier (51\%) oraz południowy Kraj Zadunajski (20\%). Tereny te charakteryzują się niewielkim stopniem uprzemysłowienia i znacznym wskaźnikiem bezrobocia, co ma istotne znaczenie dla sytuacji materialnej Romów. W samym Budapeszcie mieszka ok. 12 tys. Romów (Wójcik, 2011).

Większość programów aktywizacji zawodowej mniejszości romskiej na Węgrzech jest nieskuteczna. Brak własnej inicjatywy oraz roszczeniowa postawa, ukształtowana w poprzednim systemie społeczno-gospodarczym, powodują, że w nowych warunkach zarówno proces motywacji, jak i aktywność w poszukiwaniu pracy, a także wykazywaniu postaw przedsiębiorczych, w tym podwyższaniu własnych kwalifikacji, są dalece niewystarczające. Od $2005 \mathrm{r}$. wprowadzono na Węgrzech aż 27 programów aktywizacji zawodowej Romów, które niestety w większości okazały się nieskuteczne. W zakresie realizowania programów aktywizacji zawodowej Romów w wielu krajach sytuacja wydaje się być zatem podobna. Według Osucha i Dwojak (2009), także w Polsce - pomimo wprowadzania wielu lokalnych projektów aktywizacji zawodowej mniejszości romskiej - nie udało się ich zakończyć sukcesem ani Romom nie udało się utrzymać ich miejsc pracy na dłuższy czas. Inną kwestią jest fakt, że działania podejmowane w Polsce przez Urzędy Pracy (do czego są zobowiązane w ramach realizacji rządowego Programu na rzecz społeczności romskiej w Polsce), mające na celu aktywizację zawodową tej grupy, są dalece niewystarczające. Od 2004 do 2013 r., w kolejnych latach podejmowano rzadkie próby organizacji szkoleń podnoszących lub zmieniających kwalifikacje zawodowe Romów. Należy tu nadmienić, że nie przynosiły one efektów, a liczba przedstawicieli mniejszości romskiej w nich uczestniczących w poszczególnych województwach była bardzo niewielkie - zwykle kilka osób.

Pewnym sukcesem w tym zakresie mogą się poszczycić władze austriackiego miasta Oberwart, którym udało się na dłuższy czas stworzyć miejsca aktywizacji zawodowej dla 62 obywateli mniejszości romskiej, a zwłaszcza kobiet, realizując projekt „Mri Buti” („Moja praca”) i współpracując z austriackim Caritasem, o czym szczegółowo pisał Osuch (2008). Projekt dotyczył dalszego wykorzystania używanej odzieży dostarczanej przez Caritas ze zbiórek: prania, segregowania, wykonywania drobnych napraw - szycia, prasowania - oraz systemu jej dystrybucji do sklepów w celu sprzedaży po okazyjnych cenach. W projekcie tym pracownicy sami określili wymiar czasu pracy i stopień własnego zaangażowania, a tym samym wysokość zarobków, które były co prawda ograniczone, ale zależały od czasu pracy i poprawności wykonywanych zadań.

Także na Węgrzech w regionach objętych dużym bezrobociem spotyka się ostatnio rozwiązania polegające na obowiązku przeprowadzenia robót publicznych na rzecz miasta w zamian za zasiłek i świadczenia socjalne. Wśród obywateli wykonujących prace publiczne dość często znajdowali się również Romowie. 
Procentowy udział Romów w stosunku do obywateli Węgier jest stosunkowo wysoki, szczególnie w południowo-zachodniej i północno-wschodniej części kraju (ryc. 2). Ogółem liczba obywateli Węgier wg spisu powszechnego z 2011 r. to 9,34 mln, w tym liczba Romów to ok. 300 tys. (3,5\%), lecz jak już wspomniano wcześniej - wg szacunków romskich badaczy - w rzeczywistości jest ona znacznie wyższa.

Niezależnie jednak od przyjętej oficjalnie czy szacunkowo liczby Romów na Węgrzech, ich rozmieszczenie (ryc. 2) w dużej mierze pokrywa się z rozmieszczeniem regionów węgierskich, w których występuje zagrożenie ubóstwem (por. raport: Living conditions of the Roma: Substandard housing and health, 2011) i wysokie bezrobocie (ryc. 3).

Ryc. 2. Udział Romów wśród ogółu obywateli Węgier w 2011 r. wg mikroregionów (w \%)

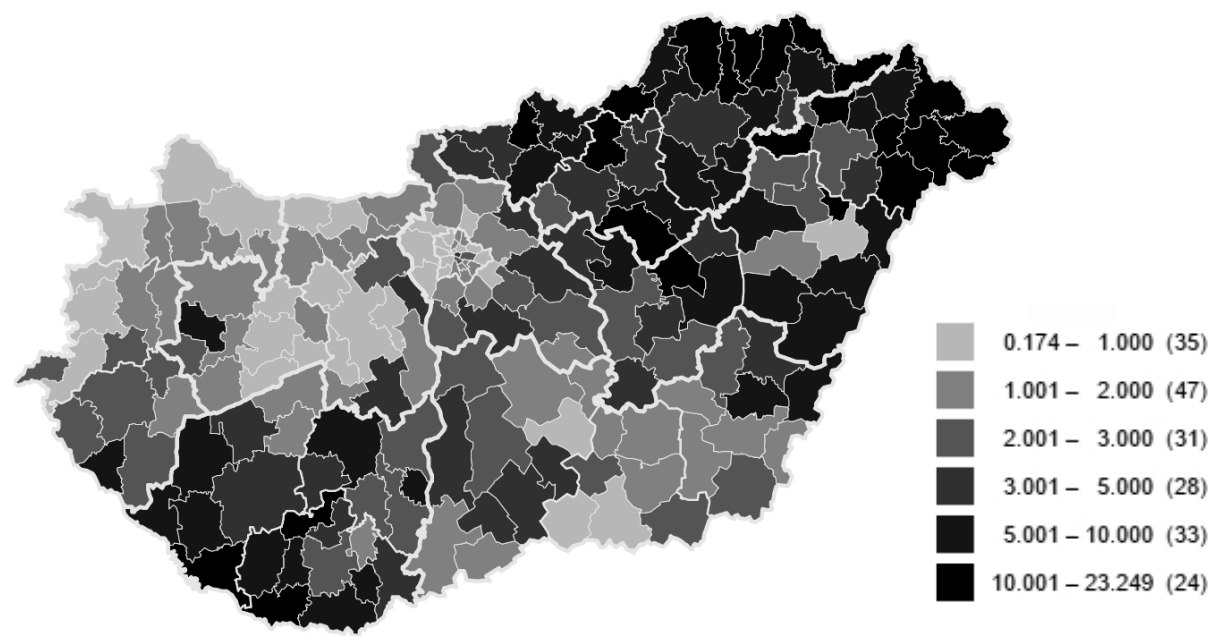

Źródło: Opracowanie własne z wykorzystaniem kreatora map i danych Węgierskiego Centralnego Urzędu Statystycznego ze spisu powszechnego w 2011 r., www.ksh.hu/interactive_humaps

Ryc. 3. Liczba bezrobotnych na 100 osób zatrudnionych na Węgrzech w 2011 r. wg mikroregionów

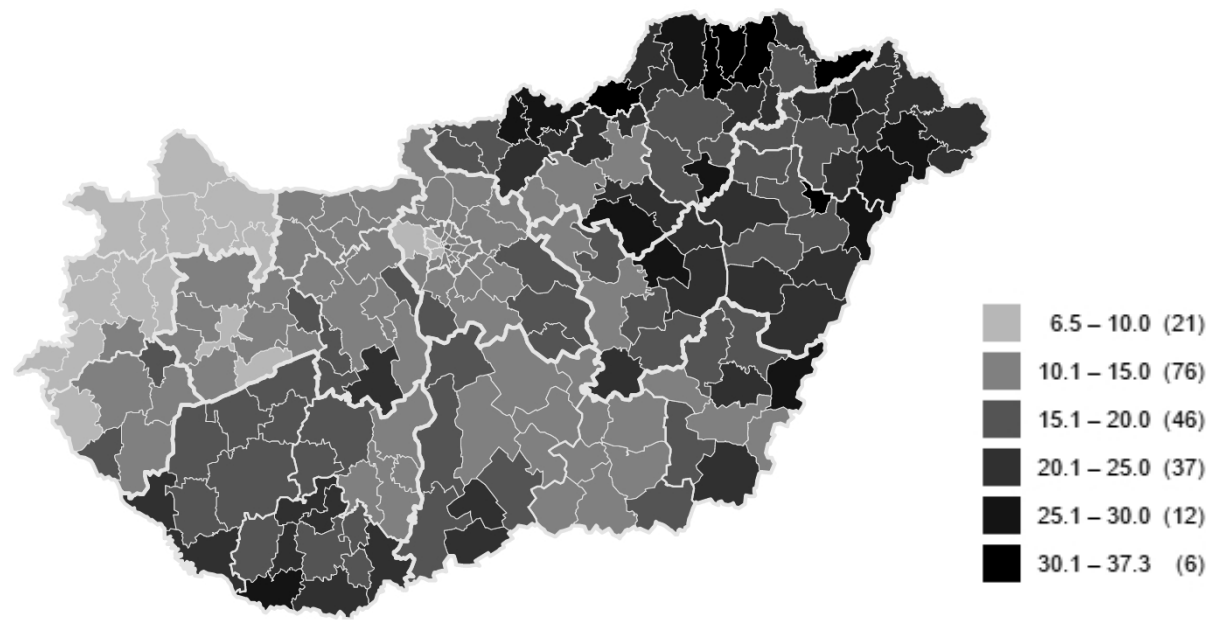

Źródło: Opracowanie własne z wykorzystaniem kreatora map i danych Węgierskiego Centralnego Urzędu Statystycznego ze spisu powszechnego w 2011 r., www.ksh.hu/interactive_humaps 
Pomimo szerokiej ochrony prawnej ze strony licznych organizacji publicznych działających na Węgrzech, w tym np. Urzędu ds. Równego Traktowania, i podjęcia przykładowo w 2010 r. aż 377 postępowań, a także działalności Programu Współpracy Narodowej, oraz Dekady Integracji Romów, nie udaje się na bieżąco rozwiązywać licznych problemów mniejszości romskiej. Dodatkowym utrudnieniem jest postępująca gettoizacja osiedli romskich na wsiach i w miastach przemysłowych oraz liczne akty dyskryminacji, a nawet agresji, także ze strony przedstawicieli węgierskiej polityki, czego najlepszym przykładem jest działalność wcześniej wspomnianej partii Jobbik.

\section{Projekt „Common Goals - Common Ways” jako próba wypracowania rozwiązań edukacyjnych dla poprawy sytuacji społecznej i ekonomicznej mniejszości romskiej na Węgrzech}

Szkolnictwo węgierskie od wielu lat zmaga się z szeregiem problemów edukacyjnych, w tym zwłaszcza z trudnościami w zakresie kształcenia i szkolenia zawodowego. Główne trudności węgierskiego systemu szkolnictwa dotyczą jednak dostosowania szkoły do pracy ze zróżnicowaną społecznie i kulturowo młodzieżą, a nade wszystko, trudności edukacyjnych uczniów romskich, braku ich motywacji do nauki oraz problemów edukacyjnych uczniów szkół zawodowych.

Przykładem międzynarodowej współpracy na rzecz walki z powyższymi problemami jest węgierski projekt współfinansowany przez Unię Europejską: „Common Goals - Common Ways", mający na celu wspieranie procesu udoskonalania jakości i innowacyjności w zakresie edukacji oraz transfer tzw. dobrych praktyk z krajów unijnych uczestniczących w projekcie. Twórcą projektu jest fundacja EduNet Foundation for New Educational Resources z siedzibą w Budapeszcie. Projekt finansowany był w ramach programu Leonardo da Vinci (Transfer of innovation, Multilateral Projects, Leonardo da Vinci Lifelong Learning Programme Education and Culture DG, „Common Goals - Common Ways” (2012-1-HU1-LEO05-05838), a jego czas trwania przewidziano na listopad 2012-grudzień 2014. Partnerami EduNet w projekcie byli przedstawiciele Niemiec: Euro-Training Centre z Monachium, Wielkiej Brytanii: Train'd Up w Menstrie koło Stirling i Polski: Uniwersytet Pedagogiczny im. Komisji Edukacji Narodowej w Krakowie - Instytut Geografii (Świętek, Osuch, 2013). Przedmiotem projektu było wypracowanie takich działań i skutecznych rozwiązań edukacyjnych, aby możliwa była adaptacja w węgierskich szkołach programów i metod zaczerpniętych z doświadczeń innych krajów - Niemiec, a szczególnie systemu edukacyjnego Bawarii, a także Szkocji i Polski - w ramach współpracy z partnerami. Autorzy projektu postawili sobie za cel walkę z niewielkim zainteresowaniem tak potrzebnym dziś kształceniem zawodowym oraz pokonanie trudności w nawiązywaniu i utrzymywaniu przez szkoły zawodowe kontaktu z realnym rynkiem pracy, a także wzbudzenie chęci świadomego planowania kariery zawodowej uczniów. Podjęte wyzwania wymagały zastosowania specyficznych narzędzi pedagogicznych i bardziej indywidualnego podejścia do ucznia. Dla osiągnięcia tego celu twórcy projektu zaprosili do współpracy przedstawicieli różnych instytucji edukacyjnych z trzech wymienionych krajów.

\section{Rozwiązania edukacyjne transferowane w ramach projektu}

Projekt „Common Goals - Common Ways” w 2014 r. był w fazie testowania. W tym czasie węgierscy partnerzy wprowadzali $\mathrm{w}$ życie zdobyte dotychczas doświadczenia w wybranych placówkach oświatowych. Ostateczne wyniki testowania oraz wdrażania poszczególnych elementów projektu pokażą, czy transfer innowacji okazał się skuteczny na gruncie węgierskim i czy sprawdzone w innych krajach rozwiązania mogą wpłynąć na jeszcze lepsze wyniki 
kształcenia uczniów oraz powinny być wprowadzane na większą skalę w węgierskim systemie edukacji (Świętek, Osuch, 2013).

Pierwszym zaczerpniętym programem jest niemiecki program orientacji zawodowej ProVib, opracowany dla uczniów w wieku 13-15 lat w Bawarii. Jego wprowadzenie na Węgrzech przede wszystkim ma na celu wzrost motywacji młodych ludzi do nauki, przez zwiększenie świadomości uczniów w wyborze ścieżki kariery zawodowej i podniesienie znaczenia kształcenia zawodowego, a także ograniczenie zjawiska porzucania szkoły. Istotnym wydaje się powołanie stanowiska nauczyciela mentora (Bildungsbegleiter) jako skutecznej pomocy w planowaniu wyboru zawodu.

Drugim programem wykorzystywanym w projekcie jest szkocki program zachęcający młodych ludzi w wieku 15-20 lat także do świadomego planowania kariery zawodowej. Autorzy projektu wyrażają przekonanie, że adaptacja tego programu prawdopodobnie podniesie odpowiedzialność młodzieży i jej zaangażowanie w aktywne kształtowanie swojej kariery. W szkockim programie istotne są metody zindywidualizowanego wsparcia uczniów uczęszczających do szkół zawodowych, które mają na celu zachęcenie ich do dzielenia się problemami szkolnymi i osobistymi z ich nauczycielami - opiekunami. Wzorując się na doświadczeniach bawarskich nauczycieli, prowadzący projekt dokonują transferu metod praktycznego szkolenia ich nauczycieli - opiekunów, np. stosując metodę drzewek decyzyjnych w wyborze ścieżki kariery zawodowej oraz metodologię badań ankietowych - diagnostycznych. Ponadto metody i sposoby budowania partnerstwa między instytucjami edukacyjnymi są kolejnymi innowacjami zaczerpniętymi od partnerów ze Szkocji. Polegają one na tworzeniu lokalnych sieci współpracy szkół, zakładów pracy, samorządów i partnerów społecznych na rzecz rozwoju społeczności lokalnej, a także wspieraniu wysiłków społeczności celem zmniejszenia współczynnika porzucania szkół przez uczniów i kontynuacji edukacji zawodowej.

Wkład polskiego partnera dla autorów projektu stanowią cenne doświadczenia w zakresie znajomości problematyki edukacji Romów, którzy są największą mniejszością etniczną na Węgrzech (jak wspominano, 3,5-10\% populacji), silnie dotkniętą problemami społecznymi i ekonomicznymi. Kluczem do poprawy sytuacji mniejszości romskiej na Węgrzech, podobnie jak w Polsce, jest jasno określona przyszłość edukacyjna ich dzieci. W ramach współpracy zapoznano węgierskich partnerów z sytuacją społeczną Romów w Małopolsce oraz organizacją szkolnictwa romskiej mniejszości etnicznej w Polsce - w tym zmianą tej organizacji w ostatnich latach i likwidacją klas romskich. Przedstawiono również sposoby pracy z dziećmi romskimi w klasach integracyjnych oraz zadania stawiane specjalnie przygotowanym do tej pracy nauczycielom wspomagającym i asystentom romskim. Zwrócono uwagę na możliwość realizacji Programu na rzecz społeczności romskiej, wskazując jego celowość, jak również niestety - ograniczoną skuteczność w niektórych jego zakresach. Za pozytywne uznano każde wsparcie finansowe związane ze wspomaganiem edukacji młodych Romów, np. wyprawki szkolne, zajęcia wyrównawcze, zajęcia dodatkowe, posiłki w szkołach, wycieczki, system stypendialny (Świętek, Osuch, 2013).

Cennym doświadczeniem partnerów projektu podczas pobytu w Polsce była wizyta w Krakowie i zapoznanie się z pracą asystenta romskiego opiekującego się specjalnie przygotowaną świetlicą integracyjną dla dzieci w tym mieście. Niestety, partnerzy węgierscy wyrazili szczere ubolewanie, że ich sytuacja finansowa nie pozwala na zatrudnienie asystentów romskich w liczbie gwarantującej skuteczność działań opiekuńczo-edukacyjnych. Wizyta w Muzeum Etnograficznym w Tarnowie pozwoliła na szczegółowe zapoznanie się z pozaszkolnymi metodami edukacji oraz integracji dzieci polskich i romskich, co także zostało wykorzystane w przekazaniu doświadczeń partnerom na niższym etapie edukacyjnym - szkoły podstawowej. 
Zespół Uniwersytetu Pedagogicznego w Krakowie dodatkowo przygotował specjalną publikację - rodzaj przewodnika dla węgierskich nauczycieli pracujących z dziećmi romskimi. Ma on pomagać nauczycielom zrozumieć odmienność kulturową Romów, diagnozować i rozwiązywać problemy integracyjne w grupie oraz trudności dzieci romskich w nauce, ale także wskazywać konkretne przykłady metod pracy z romskimi uczniami oraz ich rodzicami. Opracowanie zawiera także narzędzie diagnostyczne do badania relacji uczniów w klasach węgiersko-romskich oraz wiele innych wskazówek i informacji dla nauczycieli i wychowawców pracujących w tym środowisku.

Przewodnik zawiera szczegółowy opis sugerowanych do realizacji działań, w formie kolejnych kroków budujących skuteczną organizację edukacji romskiej mniejszości etnicznej, do których zaliczono:

- rozpoznanie sytuacji (społecznej, ekonomicznej, kulturowej) uczniów romskich i określenie ich potrzeb,

- stworzenie uregulowań prawnych dla skutecznej organizacji szkolnictwa uczniów romskich,

- przygotowanie narzędzia do realizacji prawa w zakresie edukacji dzieci romskich, m.in. stanowisk asystenta romskiego i nauczyciela wspomagającego, wraz z opisem ich zakresów obowiązków i wymaganych kompetencji,

- działania na rzecz wsparcia dzieci romskich w codziennej realizacji obowiązku szkolnego,

- korzystanie z doświadczenia najlepszych, przykładowych placówek oświatowych i instytucji skutecznie realizujących edukację uczniów romskich.

Wspomniana publikacja jest obecnie - 2014 r. - testowana w węgierskich szkołach zaangażowanych w projekt. Wyniki badań przyniosą odpowiedź, czy proponowane działania mogą się przyczynić do skutecznej realizacji edukacji dzieci romskich na Węgrzech, tak jak przyczyniają się doń w Polsce.

\section{Zakończenie}

Najważniejszym wyzwaniem zarówno dla polskiego partnera, jak i dla późniejszego transferu innowacji do węgierskich szkół była próba odpowiedzi na pytanie, jak skutecznie edukować romskie dzieci. Pytanie to przyświecało członkom polskiej grupy projektowej - autorom artykułu - w trakcie tworzenia narzędzi edukacyjnych, a następnie propozycji ich adaptacji w warunkach węgierskich. Wymagało ono od naukowców dogłębnej analizy uwarunkowań edukacji romskich uczniów (kulturowych, społecznych, ekonomicznych, prawnych), analizy zmian i obecnego stanu systemu kształcenia Romów w Polsce oraz samodzielnych badań edukacyjnych. Na ich podstawie przedstawiono również nowe propozycje rozwiązań mogących odnieść skutek w szkołach węgierskich. Polski zespół z dużymi nadziejami czeka na wyniki fazy testowej projektu. Przydatność przygotowanego przezeń narzędzia na Węgrzech będzie bowiem, prócz źródła pomocy w edukacji romskich uczniów, również dowodem na zasadność i możliwość transferu dobrych praktyk edukacyjnych między krajami Unii Europejskiej.

\section{Literatura \\ References}

Benhabib, A., Merabet, A., Benachenhou, M., Grari, Y., Boudia, F., Merabet, H. (2014). Environmental and Individual Determinants of Female Entrepreneurship in Algeria: Applying the Structural Equation Modeling. Entrepreneurial Business and Economics Review, 2(1), 65-80. 
Daszkiewicz, N., (2014). Education as a Stimulating Factor for Entrepreneurship Development, Horyzonty Wychowania, 13(26), 165-177.

Dorocki, S., Brzegowy, P. (2014). Miejsce przedsiębiorczości w systemie edukacyjnym Francji i jej wpływ na aktywizację gospodarczą regionów. O idei l'esprit d'entreprise. Horyzonty Wychowania, 13(26), 287-302.

Dorocki, S., Kilar, W., Rachwał, T. (2011). Założenia i cele Projektu „Krok w przedsiębiorczość” dla nauczycieli szkół ponadgimnazjalnych. Przedsiębiorczość - Edukacja, 7, 308-320.

Fridrich, Ch. (2006). „Other people”, „Otherness” and „Regional Identity” from the Socio-geographical Perspective. In: From the Margin to the Centre. Capturing the Perspectives of Young People from European Minority Group, ed. Ch. Fridrich, Klagenfurt: Drava Verlag, 52-64.

Grönfors, J., Trotta-Tuomi, M. (2006). The Roma Minority in Finland - an Overview. In: From the Margin to the Centre. Capturing the Perspectives of Young People from European Minority Group, ed. Ch. Fridrich, Klagenfurt: Drava Verlag, 152-155.

Jasińska-Kania, A. (2009). Wykluczanie z narodu: dystanse społeczne wobec mniejszości narodowych i migrantów. W: A. Jasińskia-Kania, S. Łodziński (red.), Obszary i formy wykluczenia etnicznego w Polsce - mniejszości narodowe, imigranci, uchodźcy. Warszawa: Wyd. Naukowe Scholar, 39-57.

Jimenez, J.J., Wach, K. (2014). The Entrepreneurial Profile of Students Participating in the Academic Entrepreneurship Source: Pilot Study Results. Horyzonty Wychowania, 13(26), 121-144.

Kézdi, G., Surányi, E. (2009). A Successful School Integration Program, An Evaluation of the Hungarian National Government's School Integration Program 2005-2007. Budapeszt: Roma Education Found.

Kemény, I., Janky, B., Lengyel, A. (2004). A magyarországi cigányság 1971-2003. Budapeszt, 37-39.

Kilar, W., Rachwał, T. (2014). Postrzeganie zakładania własnej działalności gospodarczej jako przejaw postawy przedsiębiorczej studentów kierunków nieekonomicznych. Horyzonty Wychowania, 13(28), 111-130.

Kosała, M. (2014). Badanie postaw przedsiębiorczych wśród młodzieży jako fundament kształtowania postawy odpowiadającej wyzwaniom współczesnego świata. Horyzonty Wychowania, 13(28), 317-340.

Kulig-Moskwa K., Strzelczyk A. (2014). Postawy i zachowania przedsiębiorcze studentów na przykładzie Wyższej Szkoły Bankowej we Wrocławiu - wyniki badań własnych. Horyzonty Wychowania, 13(28), 81-94.

Kurek, S., Rachwał, T. (2009). The Role of Business Education in the Development of Entrepreneurship in the Member States of the European Union. Europa XXI, 19, 127-142.

Kurek, S., Rachwał, T., Szubert, M. (2012). Kształtowanie kompetencji biznesowych uczniów gimnazjum w świetle opinii nauczycieli na podstawie wyników badań prowadzonych w ramach europejskiego projektu FIFOBI, Przedsiębiorczość - Edukacja, 8, 24-36.

Kwieciński, L., Młodzińska-Granek, A. (2014). Academic Entrepreneurship in the Humanities and Social Sciences: Research Conducted among Students of Wroclaw University, Horyzonty Wychowania, 13(26), 33-49.

Milewski, J. (2001). Romowie żyja wśród nas. Suwałki: Wydawnictwo Stowarzyszenia „Integracja”.

Mirga, A. (2010). Niechciani współobywatele. W: Przyszłość Romów w Polsce. Warszawa: Instytut Obywatelski, 23-25.

Mróz, L. (1986). Wyróżnianie grupy własnej przez Cyganów w Polsce: swojskość, inność, obcość. W: Etnografia Polska. t. XXX, z. 1, 139-162.

Nowicka, E. (2007). Romowie i świat współczesny. W: P. Borek (red.), Romowie w Polsce i Europie. Kraków: Wydawnictwo Naukowe Akademii Pedagogicznej, 124-147.

Najda, M., Wach, K. (2008). Lifelong Learning in the Fields of Tourism in the European Union Taking Poland into Special Consideration, W: M. Bednarczyk (ed.), Entrepreneurship in Tourism and Sport Business, Kraków: Fundacja dla Uniwersytetu Jagiellońskiego, 45-58.

Osuch, W. (2008). Problem aktywizacji społecznej i zawodowej romskiej mniejszości narodowej w Austrii na przykładzie miasta Oberwart. Przedsiębiorczość - Edukacja, 4, 195-201.

Osuch, W., Dwojak, A. (2009). Wspieranie przedsiębiorczości przez przeciwdziałanie marginalizacji społeczno-ekonomicznej grup nieprzystosowanych do konkurencji w gospodarce rynkowej jako dążenie do zrównoważonego rozwoju społeczeństwa informacyjnego (na przykładzie mniejszości romskiej). Przedsiębiorczość - Edukacja, 5, 244-253. 
Osuch, W., Świętek, A. (2013). Informacja o międzynarodowym projekcie „, Common Goals - Common Ways”. W: Z. Zioło, M. Borowiec (red.), Problematyka 29. Międzynarodowej Konferencji Naukowej nt. „Zmiany struktury przestrzennej przemysłu i usług w warunkach kryzysu gospodarczego”. Kraków - Warszawa: Uniwersytet Pedagogiczny im. Komisji Edukacji Narodowej. Instytut Geografii, Zakład Przedsiębiorczości i Gospodarki Przestrzennej, Polskie Towarzystwo Geograficzne, Komisja Geografii Przemysłu, 119-121.

Paszko, A., Sułkowski, R., Zawicki, M. (red.). (2007). Romowie na rynku pracy. Kraków: Małopolska Szkoła Administracji Publicznej Akademii Ekonomicznej.

Piróg, D. (2014). The impact of degree programme educational capital on the transition of graduates to the labour market. Studies in Higher Education (online), 1-15.

Piróg, D. (2015). Przechodzenie absolwentów studiów geograficznych na rynek pracy: proces, determinanty, predykcja. Kraków: Wydawnictwo Naukowe Uniwersytetu Pedagogicznego.

Poruncia, A., Nichersu, J. (2006). The Roma Minority in Romania and in Eastern Romania - an Overview. In: From the Margin to the Centre. Capturing the Perspectives of Young People from European Minority Group, ed. Ch. Fridrich, Klagenfurt: Drava Verlag, 75-83.

Probst-Thayanandasivam, S. (2006). The Roma Minority in Austria - an Overview In: From the Margin to the Centre. Capturing the Perspectives of Young People from European Minority Group, ed. Ch. Fridrich, Klagenfurt: Drava Verlag, 117-122.

Quality of life in ethnically diverse neighbourhoods. (2011). Dublin: European Foundation for the Improvement of Living and Working Conditions.

Rachwał, T. (2010). Chapter 9. Entrepreneurship Education as a Growth Stimulus for Family Firms. W: Surdej A. Wach K. (red.), Exploring the Dynamics of Entrepreneurship, Torun: A. Marszałek Publishing House, 139-156.

Rantanen, T., Pawlak, A., Toikko, T. (2015). The Significance of Social Welfare Attitudes in Young People's Entrepreneurial Intentions. Entrepreneurial Business and Economics Review, 3(1), 43-60.

Rokhman, W., Ahamed, F. (2015). The Role of Social and Psychological Factors on Entrepreneurial Intention among Islamic College Students in Indonesia. Entrepreneurial Business and Economics Review, 3(1), 29-42.

Safin, K. (2014). Przedsiębiorcze zachowania studentów - stan i konsekwencje dla dydaktyki, Horyzonty Wychowania, 13(26), 327-340.

Szymańczak, J. (2011). Społeczność Romów w Polsce. W: Analizy Biura Analiz Sejmowych, 1(45), Warszawa.

Wach, K. (2013). Edukacja na rzecz przedsiębiorczości wobec współczesnych wyzwań cywilizacyjno-gospodarczych. Przedsiębiorczość - Edukacja, 9, 246-257.

Wach, K. (2014). Edukacja dla przedsiębiorczości: pomiędzy przedsiębiorczą pedagogiką a edukacją ekonomiczną i biznesową. Horyzonty Wychowania, 13(28), 11-32.

Wach, K. (2015). Środowisko biznesu rodzinnego jako stymulanta intencji przedsiębiorczych młodzieży akademickiej, Przedsiębiorczość i Zarządzanie, 16(7/3), 25-40.

Wójcik, K. (2011). Sytuacja prawna i społeczna Romów na Wegrzech. W: A. Frąckowiak-Adamska, A. Śledzińska-Simon (red.), Sytuacja prawna i społeczna Romów w Europie. Prace Naukowe Wydziatu Prawa, Administracji i Ekonomii Uniwersytetu Wrocławskiego, 12, Uniwersytet Wrocławski, 141-161.

Zbierowski, P. (2014). Determinanty intencji przedsiębiorczej studentów - wyniki badań. Horyzonty Wychowania, 13(28), 51-63.

\section{Źródla internetowe:}

Program na rzecz społeczności romskiej w Polsce na lata 2004-2013. (2013, 2 lutego). Pozyskano z: http://www.msw.gov.pl/portal/pl/185/2982/Tresc_Programu.html

Sprawozdania z realizacji Programu na rzecz społeczności romskiej w Polsce za lata 2004-2012. (2013, 2 lutego). Pozyskano z: http://mniejszosci.narodowe.mac.gov.pl/mne/romowie/program-na-rzecz-spole/program-na-rzecz-spole/program-na-rzecz-spole-1/6978,Sprawozdania-z-realizacji-Pro gramu-na-rzecz-spolecznosci-romskiej-w-Polsce-w-201.html 
Unijne ramy dotyczace krajowych strategii integracji Romów do 2020 r., KOM 2011 nr 173, Komunikat Komisji do Parlamentu Europejskiego, Rady, Europejskiego Komitetu Ekonomiczno-Społecznego i Komitetu Regionów. (2013, 12 lutego). Pozyskano z: http://eur-lex.europa.eu/LexUriServ/ LexUriServ.do?uri=COM:2011:0173:FIN:PL:PDF

Living conditions of the Roma: Substandard housing and health. (2012). European Foundation for the Improvement of Living and Working Conditions. Pozyskano z:

http://www.eurofound.europa.eu/publications/htmlfiles/ef12021.htm

http://wyborcza.pl/1,76842,14270513, Slowacy_oddzielili_Romow_kolejnym_murem.html http://www.polskieradio.p1/5/3/Artykul/988624,Policja-zlikwidowala-obozowisko-Romow-pod-

Paryzem

http://metro.gazeta.pl/Wydarzenia/1,133290,15759142,Rozmowa_z_Michalem_Syska_dyrektorem_ Osrodka_Mysli.html

Agnieszka Świętek, dr, Uniwersytet Pedagogiczny im. Komisji Edukacji Narodowej w Krakowie, Instytut Geografii, Zakład Dydaktyki Geografii.

Urodzona w Krakowie, absolwentka kierunku geografia na Uniwersytecie Pedagogicznym w Krakowie, doktor nauk o Ziemi w zakresie geografii. Jest pracownikiem naukowo-dydaktycznym na stanowisku adiunkta w Zakładzie Dydaktyki Geografii Instytutu Geografii Uniwersytetu Pedagogicznego im. KEN. Prowadzi zajęcia dydaktyczne m.in. z dydaktyki geografii, edukacji regionalnej i regionu Małopolska. Jej zainteresowania obejmują trzy zakresy badawcze: dydaktykę geografii, problematykę przedsiębiorczości oraz sytuację romskiej mniejszości etnicznej w Polsce.

Agnieszka Świętek, PhD., Pedagogical University of Cracow, Institute of Geography, Department of Didactics of Geography.

Was born in Cracow and graduated from the Faculty of Geography at the Pedagogical University of Cracow, $\mathrm{PhD}$. in geography. She is a university lecturer employed in the Department of Didactic Geography, Institute of Geography at the Pedagogical University of Cracow. She runs classes from: geography teaching, regional education, Malopolska region. Her interests comprise three research areas: geographical education, issues of entrepreneurship and the situation of Roma ethnic minority in Poland.

Adres/Address: Uniwersytet Pedagogiczny im. Komisji Edukacji Narodowej w Krakowie Instytut Geografii

Zakład Dydaktyki Geografii

ul. Podchorążych 2

30-084 Kraków, Polska

e-mail: swietekaga@wp.pl

Wiktor Osuch, $\quad$ dr hab., profesor Uniwersytetu Pedagogicznego, Uniwersytet Pedagogiczny im. Komisji Edukacji Narodowej w Krakowie, Instytut Geografii, Zakład Dydaktyki Geografii. Urodzony w Krakowie. Absolwent kierunku geografia na Uniwersytecie Pedagogicznym im. KEN. Doktor habilitowany nauk społecznych. Jest pracownikiem naukowo-dydaktycznym w Zakładzie Dydaktyki Geografii, Instytutu Geografii Uniwersytetu Pedagogicznego im. KEN. Prowadzi zajęcia dydaktyczne m.in. $\mathrm{z}$ dydaktyki geografii $\mathrm{w}$ gimnazjum i w szkole ponadgimnazjalnej, komunikacji interpersonalnej. Jest opiekunem praktyk zawodowych studentów, prowadzi seminarium magisterskie z zakresu koncepcje i praktyki wychowania. Zainteresowania naukowe autora $\mathrm{w}$ obrębie dydaktyki geografii obejmują: kształcenie nauczycieli, praktyki nauczania w szkole, profesjonalne kompetencje nauczycieli geografii, kompetencje kluczowe, metody kształcenia, programy nauczania i podręczniki. 
Wiktor Osuch, $\quad \mathrm{PhD}$., associate professor at Pedagogical University of Cracow, Institute of Geography, Department of Didactics of Geography.

Born in Cracow and graduated from the Faculty of Geography at the Pedagogical University of Cracow, Associate Professor in the field of social sciences. He is a university lecturer employed in the Didactics of Geography Department, Institute of Geography at the Pedagogical University of Cracow.

Teaching Duties (courses taught): Geography education - Didactic geography in lower and upper secondary schools, Interpersonal communication, Student's teaching practice, Concepts of the education internships, Didactic geography seminar. Research Interest in the field of didactic geography: teacher's education, teaching practice, geography teacher's professional competences, key competences,teaching methods, geography curriculum and school-books.

Adres/Address: Uniwersytet Pedagogiczny im. Komisji Edukacji Narodowej w Krakowie Instytut Geografii

Zakład Dydaktyki Geografii

ul. Podchorążych 2

30-084 Kraków, Polska

e-mail: wiktor_osuch@wp.pl

Tomasz Rachwal, dr, Uniwersytet Pedagogiczny im. Komisji Edukacji Narodowej w Krakowie, Instytut Geografii, Zakład Przedsiębiorczości i Gospodarki Przestrzennej.

Członek Krajowej Rady Przedsiębiorczości. Pełni m.in. funkcję Kierownika Zakładu Przedsiębiorczości i Gospodarki Przestrzennej Instytutu Geografii Uniwersytetu Pedagogicznego im. KEN w Krakowie, Sekretarza Naukowego Komisji Geografii Przemysłu Polskiego Towarzystwa Geograficznego, Zastępcy Redaktora Naczelnego czasopism: Przedsiębiorczość - Edukacja, Prace Komisji Geografii Przemystu Polskiego Towarzystwa Geograficznego, Annales Universitatis Paedagogicae Cracoviensis Studia Geographica oraz członka redakcji Entrepreneurial Business and Economics Review. Autor lub współautor podręczników szkolnych i akademickich z zakresu geografii ekonomicznej i przedsiębiorczości. Jego zainteresowania badawcze skupiają się przede wszystkim na problematyce przemian struktur przestrzennych przemysłu, funkcjonowania różnych branż działalności gospodarczej, restrukturyzacji przedsiębiorstw oraz roli przedsiębiorczości w rozwoju układów przestrzennych, a także edukacji w zakresie przedsiębiorczości.

Tomasz Rachwal, PhD. Pedagogical University of Cracow, Institute of Geography, Department of Entrepreneurship and Spatial Management

Member of the National Council for Entrepreneurship. Head of Department of Entrepreneurship and Spatial Management of Institute of Geography of the Pedagogical University of Cracow, Scientific Secretary of the Industrial Geography Commission of the Polish Geographical Society, Deputy Editor in Chief of the following journals: Entrepreneurship - Education, Studies of the Industrial Geography Commission of the Polish Geographical Society, Annales Universitatis Paedagogicae Cracoviensis Studies Geographica, and member of the editorial board of Entrepreneurial Business and Economics Review. Author or co-author of school and academic textbooks on economic geography and entrepreneurship. His research interests focus primarily on the issue of change of spatial structures of industry, the functioning of various branches of industrial activity, corporate restructuring and the role of entrepreneurship in the development of spatial systems as well as entrepreneurship education. 
Adres/Address: Uniwersytet Pedagogiczny im. Komisji Edukacji Narodowej

Instytut Geografii

Zakład Przedsiębiorczości i Gospodarki Przestrzennej

ul. Podchorążych 2

30-084 Kraków, Polska

e-mail: T.Rachwal@up.krakow.pl

Sławomir Kurek, dr hab., profesor Uniwersytet Pedagogiczny im. Komisji Edukacji Narodowej w Krakowie, Instytut Geografii, Zakład Geografii Społeczno-Ekonomicznej.

Geograf społeczno-ekonomiczny. Członek Komitetu Nauk Demograficznych PAN. Pełni m.in. funkcję zastępcy dyrektora Instytutu Geografii ds. Nauki i Współpracy Zagranicznej, kierownika studiów doktoranckich z geografii oraz redaktora naczelnego czasopisma Annales Universitatis Paedagogicae Cracoviensis, Studia Geographica. Jego zainteresowania badawcze skupiają się przede wszystkim na problematyce przemian struktur społeczno-demograficznych Polski i Europy, procesów suburbanizacji w obszarach metropolitalnych oraz edukacji w zakresie przedsiębiorczości.

Slawomir Kurek, PhD, associate professor at the Pedagogical University of Cracow, Institute of Geography, Department of Socio-Economic Geography.

A socio-economic geographer. Member of the Committee on Demographic Studies of the Polish Academy of Sciences. He is, among other activities, the Deputy Head for Research and International Relations of Institute of Geography, Head of Doctoral Studies in geography at the Pedagogical University, and Editor in Chief of Annales Universitatis Paedagogicae Cracoviensis, Studia Geographica. Research interests focus primarily on the issue of changes of the socio-demographic structures in Poland and Europe, suburbanisation processes in metropolitan areas, as well as entrepreneurship education.

Adres/Address: Uniwersytet Pedagogiczny im. Komisji Edukacji Narodowej w Krakowie Instytut Geografii

Zakład Geografii Społeczno-Ekonomicznej

ul. Podchorążych 2

30-084 Kraków, Polska

e-mail: sgkurek@up.krakow.pl

Niniejsza publikacja powstała $w$ ramach realizacji międzynarodowego projektu transferu innowacji „Common Ways - Common Goal” przy wsparciu finansowym Komisji Europejskiej.

Publikacja odzwierciedla jedynie stanowisko jej autorów i Komisja Europejska nie ponosi odpowiedzialności za umieszczona w niej zawartość merytoryczna.
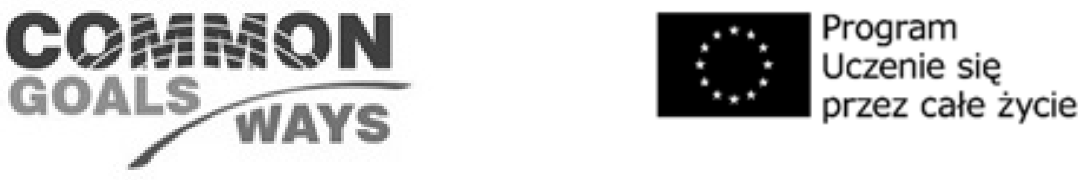